\title{
Three-dimensional printing-assisted surgical technique with limited operative exposure for both-column acetabular fractures
}

\author{
Hyun-Chul Shon, M.D., Seungmyung Choi, M.D., Jae-Young Yang, M.D.
}

Department of Orthopedic Surgery, College of Medicine, Chungbuk National University, Cheongju-Korea

\begin{abstract}
BACKGROUND: It is often difficult to achieve satisfactory reduction and fixation of both-column acetabular fractures owing to the complexity of the regional anatomy of the pelvis and the fracture configuration, which is commonly associated with a high degree of comminution. Herein, we describe the use of a three-dimensional (3D) patient-specific printed model of the pelvis to facilitate preoperative planning, simulate the fracture reduction procedure, and pre-contour the fixation plates for treating both-column acetabular fractures.
\end{abstract}

METHODS: The 3D-printed model was constructed using a fused deposition modeling method with computed tomography images as inputs. Operative and clinical outcomes were evaluated for 5 patients with both-column acetabular fractures (mean age: $4 \mathrm{I} .4$ years). The status of fracture reduction was classified using the Matta criteria, and the functional outcome was assessed using the modified Merle d'Aubigne score.

RESULTS: Reduction was classified as excellent in 4 patients and good in I patient, and good functional outcomes were achieved in all patients at the final follow-up. The average incision length was $6.9 \mathrm{~cm}$ with an average operative time of $124 \mathrm{~min}$.

CONCLUSION: We successfully applied 3D printing for the surgical management of both-column acetabular fractures, thereby improving surgical outcomes while achieving good-to-excellent reduction and good medium-term functional outcomes.

Keywords: Acetabulum; both-column fracture; limited exposure; preoperative planning; three-dimensional printing.

\section{INTRODUCTION}

It is essential to achieve anatomical reduction and hip joint congruency, including secondary surgical congruency, of both-column acetabular fractures for rapid postoperative recovery and early rehabilitation as well as maintaining longterm hip joint function. ${ }^{[1-7]}$ The treatment of both-column acetabular fractures is technically challenging owing to the complex regional anatomy of the pelvis and the complicated fracture configurations. Moreover, these injuries are located deep within the pelvis and are anatomically surrounded by major organs and neurovascular structures; thus, securing an adequate surgical field of view is generally difficult. A wide operative exposure approach can improve the field of view but can increase the risk of major complications, including infection and impaired wound healing. It can also prolong the operative time and increase the volume of blood loss and the extent of soft tissue injury during the surgical procedure. ${ }^{[8-11]}$ The severity of the injury itself and associated injures further influence the risk of mortality and postoperative complications. ${ }^{[2]}$ Therefore, limiting the surgical field as much as possible can lower the risk of postoperative morbidities, particularly in patients with comminuted acetabular fractures or multiple associated injuries.

Cite this article as: Shon HC, Choi S, Yang JY. Three-dimensional printing-assisted surgical technique with limited operative exposure for both-column acetabular fractures. Ulus Travma Acil Cerrahi Derg 2018;24:369-375.

Address for correspondence: Seungmyung Choi, M.D.

I sunhwanro 776 (Gaesindong) Cheongju - South Korea

Tel: 82-43-269-6077 E-mail: davidchoil530@gmail.com 
Ongoing developments in three-dimensional (3D) printing technology have extended the application of this technology to surgical planning of orthopedic trauma cases. Three-dimensional printed models offer several advantages over radiography and computed tomography imaging for surgical planning, the most important of these being an enhanced understanding of the 3D complexity of a fracture and providing necessary measurements for increasing the accuracy of intraoperative procedures. ${ }^{[6,7,11,13-18]}$ To date, the application of 3D printing technology for assessing and surgically treating bothcolumn acetabular fractures has not been comprehensively investigated. Therefore, in the present technical report, we describe our novel 3D-printing-assisted technique for preoperative planning and guidance of surgical procedures for managing both-column acetabular fractures with an aim of limiting operative exposure and saving operative time. We hypothesized that our 3D-printing-assisted surgical technique with limited operative exposure can achieve satisfactory reduction and fixation of both-column acetabular fractures, decrease the operative time and blood loss, and prevent postoperative complications. To evaluate the clinical feasibility of our technique, the clinical outcomes were analyzed over a mean follow-up period of 33.5 months in 5 patients with comminuted both-column acetabular fractures treated using our system.

\section{MATERIALS AND METHODS}

Patient-specific computed tomography (CT) images of the pelvis were obtained using a slice thickness of $\mathrm{I} \mathrm{mm}$ and saved in the Digital Imaging and Communications in Medicine (DICOM) format. A volume rendering technique was used to visualize the fracture fragments and remove surrounding tis- sues. From the rendered volume, a 3D graphic model of the fracture was created and stored in the Standard Triangulation Language file format for use as an input to the 3D-printing machine file. The final files were printed using a commercially available printer, the EDISON 3D PRINTERTM (Rocket Co., Ltd., Seoul, Korea). The model was constructed using a degradable plastic. From the CT image inputs, the model was constructed within $3 \mathrm{~h}$ at an approximate cost of $\$ 30$. The $3 \mathrm{D}$ printer used a fused deposition modeling (FDM) method that relies on a layer-by-layer process to construct $3 \mathrm{D}$ objects.

Once the full-size pelvis model was fabricated, the fracture lines were marked using an oil-based paint marker. After cutting along the marked fracture lines, each fracture fragment was separated using a craft knife, with the free fragments used to simulate the surgical procedure for fragment reduction and fixation in vitro. After achieving satisfactory reduction, temporary fixation of the fracture was performed using glue (Fig. Ia-f). The appropriate positioning of the fixation plate was then selected, including the location of the holes to use in the plate. The reconstruction osteosynthesis plating system (Synthes, Solothurn, Switzerland) was then precontoured and assembled to fit the real-size patient-specific pelvic model (Fig. 2). The pre-contoured plate was sterilized and stored until intraoperative application. Both-column acetabular fractures were managed by open reduction and internal fixation using a modified Stoppa limited approach. The patient was positioned supine, and hip flexion was performed to relax the iliopsoas muscle, the external iliac and femoral neurovascular bundle, and the abdominal muscles. A transverse incision was made $3 \mathrm{~cm}$ above the pubic symphysis.
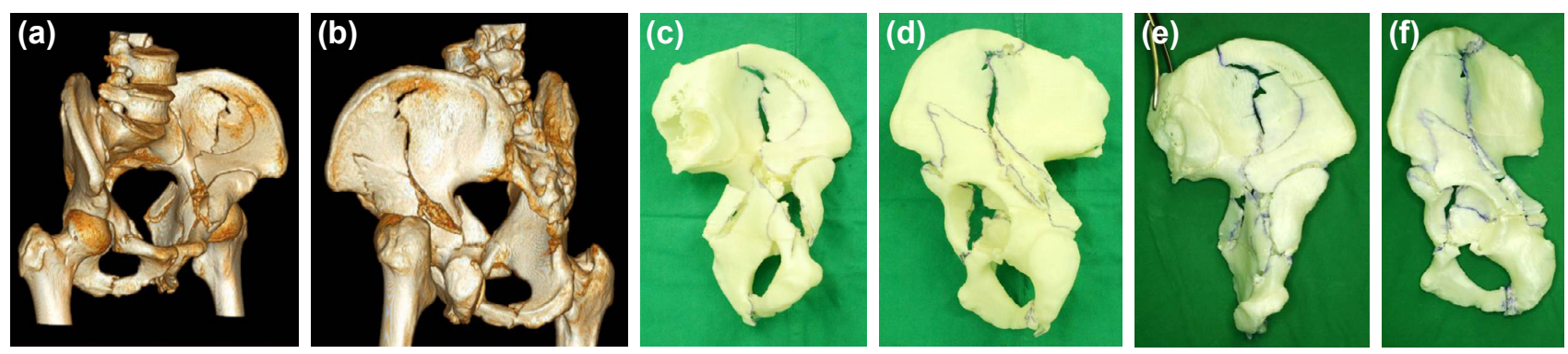

Figure 1. (a) Three-dimensional reconstructed computed tomography scans showing a both-column fracture of the left acetabulum (a, b). The fracture lines are marked (c, d), and temporary fixation of the fracture is performed using glue (e, f).
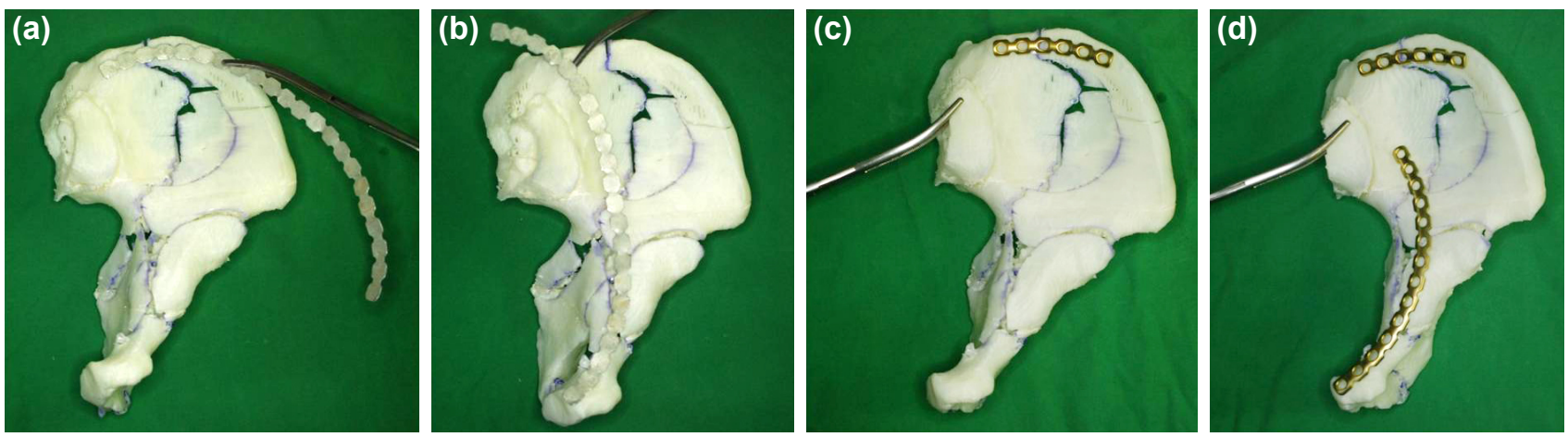

Figure 2. (a-d) Clinical photographs showing the sequential templating and plate pre-contouring technique. 
Table I. Demographic data and selected clinical characteristics of patients

\begin{tabular}{|c|c|c|c|c|}
\hline Patient & $\begin{array}{c}\text { Age } \\
\text { (years) }\end{array}$ & Sex & $\begin{array}{l}\text { Mechanism } \\
\text { of injury }\end{array}$ & $\begin{array}{l}\text { Concomitant } \\
\text { injuries }\end{array}$ \\
\hline 1 & 23 & Female & Fall & $\begin{array}{c}\text { Sacral fracture } \\
\text { Hemoperitonium } \\
\text { Spinal fracture }\end{array}$ \\
\hline 2 & 45 & Male & Fall & $\begin{array}{c}\text { Distal radius fracture } \\
\text { Hemoperitonium }\end{array}$ \\
\hline 3 & 49 & Male & MVA & $\begin{array}{l}\text { Spinal fracture } \\
\text { Tibiofibular fracture } \\
\text { Calcaneal fracture } \\
\text { Hemoperitonium }\end{array}$ \\
\hline 4 & 39 & Female & MVA & $\begin{array}{c}\text { Hemoperitonium } \\
\text { Urethral injury } \\
\text { Spinal fracture } \\
\text { Distal radius fracture } \\
\text { Femoral fracture }\end{array}$ \\
\hline 5 & 51 & Male & MVA & $\begin{array}{l}\text { Urethral injury } \\
\text { Femoral fracture } \\
\text { Tibiofibular fracture } \\
\text { Calcaneal fracture }\end{array}$ \\
\hline
\end{tabular}

MVA: Motor vehicle accident.

The incision was deepened to the rectus abdominis, passing the abdominal fascia to approach the internal aspect of the pelvis. On approaching, the corona mortis was identified and ligated, and sub-periosteal dissection was performed to expose the fracture fragments. If necessary, a lateral window of $4 \mathrm{~cm}$ along the iliac crest was made to approach the fracture extending to the iliac crest or posterior column fracture.

Between October 2012 and January 2014, 12 consecutive patients with both-column acetabular fractures were surgically managed. To evaluate the clinical feasibility of our 3D printing approach, only patients who had comminuted both-column acetabular fractures with multiple associated injuries were included in the study. A total of 5 patients with a follow-up of more than 2 years were analyzed. Clinical and radiolog- ical outcomes were evaluated intraoperatively, immediately postoperatively, and subsequently over a mean postoperative follow-up of 33.5 months.

The study was approved by the institutional review board of Chungbuk National University. Patients provided informed consent for the surgical procedure, use of their data in the analysis of outcomes, and publication of the results.

\section{RESULTS}

\section{Patients' Demographics and Outcomes}

The study cohort included 2 women and 3 men with a mean age of 41.4 years and a mean postoperative follow-up of 33.5 months. The mechanism of injury was a motor vehicle crash in 3 cases and fall from a height in 2 cases. Concomitant injuries included intra-abdominal injuries in 4 cases, urethral injury in 2 cases, a distal radius fracture in 2 cases, spinal fractures in 3 cases, a sacral fracture in I case, femoral fracture in 2 cases, tibiofibular fracture in 2 cases, and calcaneal fracture in 2 cases (Table I).

All patients underwent internal fracture fixation using a modified Stoppa limited approach with an average incision length of $6.6 \mathrm{~cm}$. The average operative time was $125 \mathrm{~min}$, with an average estimated volume of blood loss of $282 \mathrm{~mL}$. According to the Matta criteria, ${ }^{\left[{ }^{[}\right]}$fracture reduction was judged to be excellent in 4 patients and good in I patient. With regard to functional outcomes assessed using the modified Merle D'aubigne score, ${ }^{[19]}$ all patients reported a good functional recovery. No instances of delayed incision healing, infection, or nonunion were identified (Table 2).

\section{Case}

A 23-year old woman (patient I) fell from a height and was admitted to our emergency department with a chief complaint of pain in her right pelvis. Radiographs and CT scans revealed a comminuted both-column fracture of the right acetabulum with a non-displaced sacral fracture. Other identified injuries included a hemoperitoneum and a fracture of the body of the second lumbar vertebra. Owing to the complex configuration of fracture fragments and multiple associated injuries, conventional surgical techniques for fracture reduction and

Table 2. Clinical outcomes of patients following the surgical procedure

\begin{tabular}{|c|c|c|c|c|c|}
\hline Patient & $\begin{array}{l}\text { Incision length } \\
(\mathbf{c m})\end{array}$ & $\begin{array}{l}\text { Operation time } \\
\text { (min) }\end{array}$ & $\begin{array}{l}\text { Estimated volume of } \\
\text { blood loss }(\mathrm{mL})\end{array}$ & Matta's criteria & $\begin{array}{l}\text { Modified Merle } \\
\text { d'Aubigne score }\end{array}$ \\
\hline I & 7 & 119 & 245 & Good & Good \\
\hline 2 & 5 & 109 & 215 & Excellent & Good \\
\hline 3 & 8 & 154 & 350 & Excellent & Good \\
\hline 4 & 6 & 124 & 324 & Excellent & Good \\
\hline 5 & 7 & 121 & 276 & Excellent & Good \\
\hline
\end{tabular}


fixation would have required a wide operative exposure to obtain a satisfactory surgical view; this would have increased the risk for postoperative complications, particularly wound infection. Therefore, the decision was made to perform 3D printing-assisted preoperative planning and surgical procedure with a limited operative exposure.

Preoperatively, a 3D printed patient-specific pelvic model was constructed from the CT images obtained upon admission (Fig. 3a-c). The procedure for fracture reduction was simulated, followed by pre-contouring of $3.5-\mathrm{mm}$ reconstruction plates ( 14 holes per plate for the anterior column). Data regarding the optimal points of entry and the position, direction, and length of the screw for fixation of the iliac crest fracture were also obtained from the model. The model provided an enhanced understanding of the association between the quadrilateral plate and the fracture fragments of the poste- rior column. Based on this data, it was decided that a limited Stoppa approach would be sufficient to perform fracture reduction and fixation.

Two separate skin incisions were made: a transverse incision, $3 \mathrm{~cm}$ above the pubic symphysis, and a lateral window of 4 $\mathrm{cm}$ along the iliac crest. Reduction of the anterior column was achieved using reduction clamps, followed by insertion of a cancellous screw to stabilize the iliac crest fracture. The pre-contoured 14-hole plate was then introduced without requiring further adjustment of the fracture fragments as the location and depth of fixation screws used to stabilize the posterior column fragment were determined during the preoperative planning phase. The status of reduction was confirmed by fluoroscopy. Postoperative radiographs and CT scans were obtained to confirm that an appropriate reduction had been achieved, with no evidence of intra-articular screw
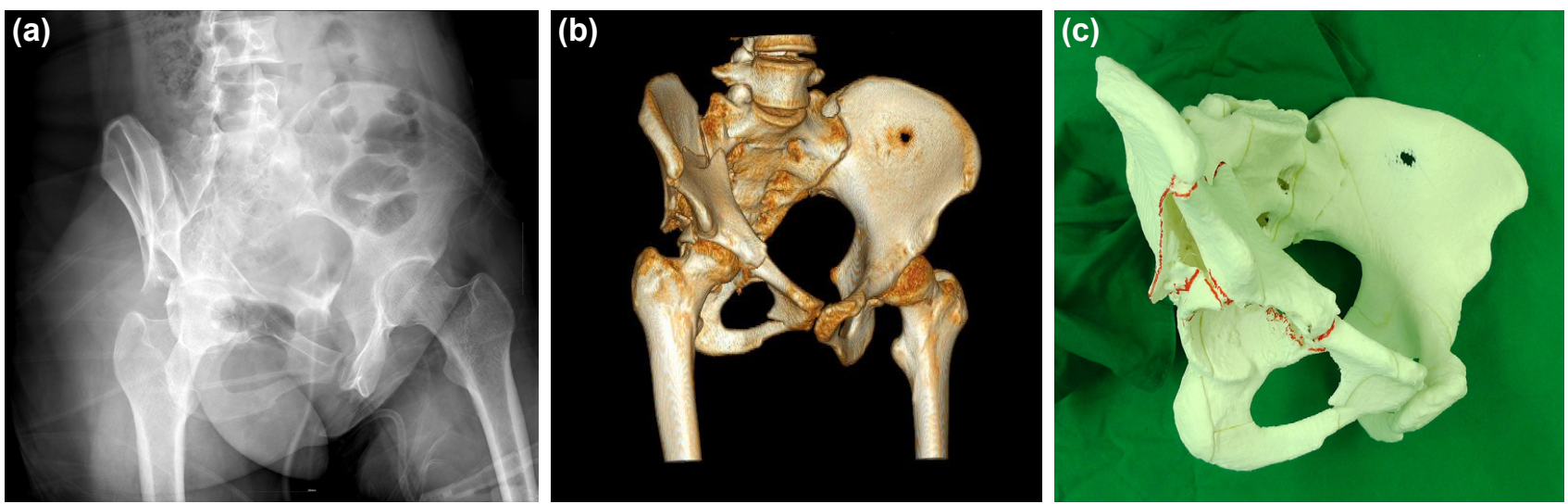

Figure 3. Image summary of the preoperative assessment of the both-column fracture of the right pelvis, showing the obturator oblique plain radiograph (a), computed tomography scans of the same view (b), and the three-dimensional printed model of the whole pelvis (c).
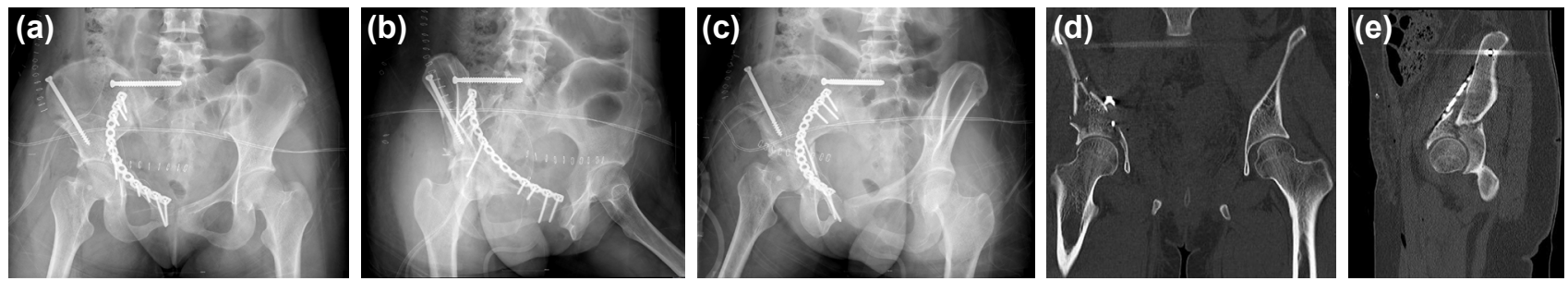

Figure 4. The status of fracture reduction and fixation verified through immediate postoperative plain radiographs (a-c) and computed tomography scans (d, e).
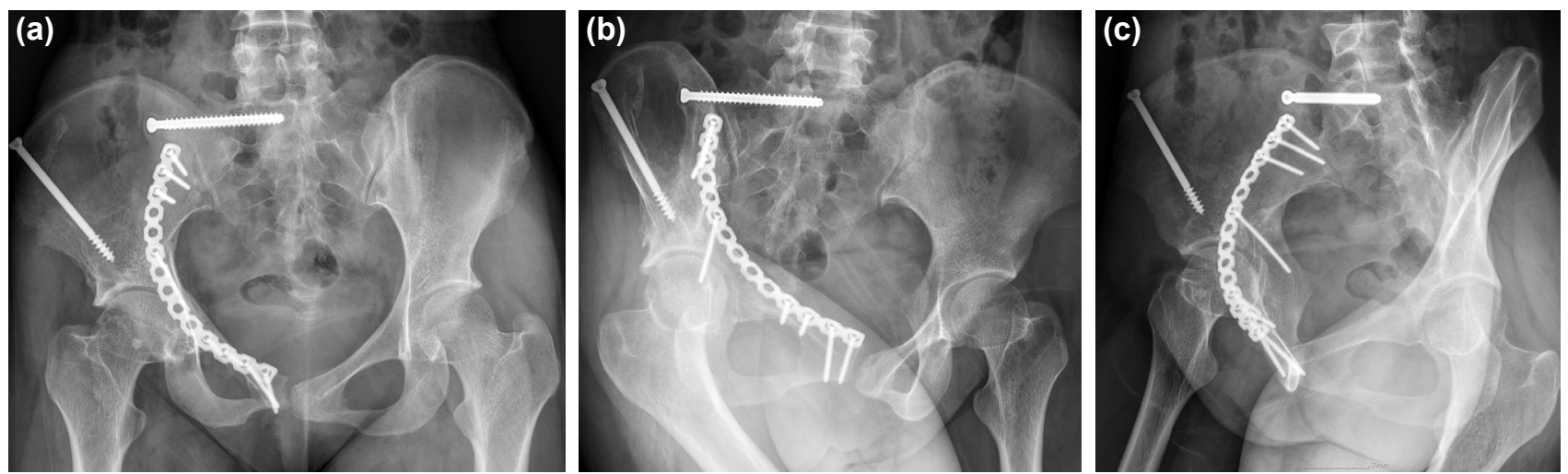

Figure 5. (a-c) A plain radiograph showing well maintained fixation and consolidation at 18 months postoperatively. 
penetration (Fig. 4a-e). Partial weight bearing was permitted 3 days postoperatively. The internal fixation was well maintained, as shown in plain radiographs obtained at 18 months postoperatively (Fig. 5).

In terms of operative data, the estimated incision length was $7 \mathrm{~cm}$ with an operation time of $119 \mathrm{~min}$ and blood loss of 245 $\mathrm{mL}$. The status of reduction was classified as good based on the Matta criteria, with a good functional outcome reported by the patient using the modified Merle d'Aubigne score. The incision healed well without evidence of infection, and postoperative union of the fracture fragments was confirmed.

\section{DISCUSSION}

Hurson et al. ${ }^{[6]}$ reported that a rapid prototyping process with selective laser sintering facilitated rapid manufacturing of accurate 3D physical models of the bony pelvis for use in preoperative assessment and classification of acetabular fractures and for treatment planning. However, their model was not integrated into surgical management, unlike our system in which the 3D model was applied to identify the best reduction technique, select and pre-contour the fixation plate, and identify the optimal location and depth of the fixation screws as well as optimal entry points. In the present technical report, we provide evidence of the feasibility of our technique to achieve satisfactory reduction and fixation of both-column acetabular fractures. In addition to facilitating preoperative planning to achieve a good-to-excellent reduction of the fracture, our model-based planned approach decreased the operative time and volume of blood loss, reduced the required length of the incision, and prevented postoperative complications. As a qualitative comparison of the operative effectiveness of our approach, our outcomes were compared with those of Sagi et al. ${ }^{[9]}$ who reported an average operative time of $263 \mathrm{~min}$ with a volume of blood loss of $750 \mathrm{~mL}$ using an anterior approach for the reduction and fixation of acetabular fractures. Therefore, although statistical analysis of our results was not feasible owing to the small sample size, we have provided preliminary evidence of the superiority of our model-based approach compared to conventional techniques in reducing the operative time and volume of blood loss.

Previous studies have reported operative outcomes using $3 \mathrm{D}$ printing for the planning of surgical procedures to treat unstable pelvic fractures. Zeng et al. ${ }^{\left[{ }^{11]}\right]}$ reported an average operative time of $110 \mathrm{~min}$ with an average volume of blood loss of $320 \mathrm{~mL}$. For 2 patients with acetabular fractures, $\mathrm{Wu}$ et al. ${ }^{[10]}$ reported an average operative time of $146 \mathrm{~min}$ with an average volume of blood loss of $450 \mathrm{~mL}$. Using the modified Stoppa approach for acetabular fractures, Kim et al. ${ }^{[20]}$ required an incision length $\geq 12 \mathrm{~cm}$ and reported a postoperative complication rate of $14 \%$. Matta et al. ${ }^{[21]}$ reported a postoperative complication rate of $13 \%$ with the use of an ilioinguinal approach. In their case series evaluating the use of $3 \mathrm{D}$ printing for treating acetabular fractures, Zeng et al. ${ }^{[\mathrm{II}}$ identified a postoperative complication in only I of their 38 patients. These low rates of postoperative complications are consistent with our results.

As several authors have demonstrated, 3D printing techniques are particularly useful for managing comminuted fractures, which require an enhanced understanding of the complex configuration of fracture fragments ${ }^{[14,15,22,23]}$ or fractures with associated injuries known to be important prognostic factors of clinical outcome. ${ }^{[10,24,25]}$ Moreover, the limited surgical field required when using a model-based approach for surgical planning may minimize soft tissue trauma and prevent injury to essential structures, such as the inguinal canal, thereby lowering the overall risk for postoperative complications in comparison to a wide operative exposure. ${ }^{[10,11,13]}$ However, future studies with larger populations followed-up over a longer period are required to clarify the effectiveness of our 3D printed model-based technique for treating comminuted both-column acetabular fractures and confirm its advantages over conventional operative procedures.

One of the disadvantages of this limited approach is that the visualization of fractures and subsequent contouring of the plate and fixation are restricted. In our study, the plate was pre-contoured to the 3D-printed model, and appropriate positioning of the plate, including the screw trajectory, was determined preoperatively. The advantages of pre-contouring the plate with limited operative exposure include a decrease in soft tissue injuries during the surgical procedure owing to soft tissue handling as least as possible. In addition, this limited approach can reduce operation time, blood loss, and risk of postoperative infection. Radiation exposure by fluoroscopic imaging is also decreased as no further contouring of the plate or adjustment of the screw trajectory is required.

The high cost and time required to fabricate printed models have been described as drawbacks of 3D printing techniques. We circumvented these issues by using the FDM technique, which is widely available and is being used for rapid manufacturing of physical products. Although the FDM technique may be considered inadequate in terms of accuracy and quality of completion of the model, the technique has the distinct advantage of providing a relatively rapid manufacturing time for the model at a low cost (i.e., $3 \mathrm{~h}$ of manufacturing time at a cost of $\$ 30$ in our study). Wang et al. ${ }^{[7]}$ reported that the geometry of the 3D printed model of the pelvis created using the FDM technique was not statistically different from that of the original pelvis. Therefore, the 3D printed model of the pelvis is deemed to have sufficient specifications for clinical practice.

A limitation of the 3D printing technique used in our study was that the model could only be fabricated in one connected form. Therefore, a displaced fracture or a gap between fracture fragments was expressed as a connected entity that was cut out and separated after the model was fabricated. This 
approach might distort the configuration of fractures with severe comminution. Additionally, as our aim was to minimize fabrication time and cost, attention was placed on developing a real-size model with the accuracy of the gross shape of the pelvis maintained during the volume rendering process but not necessarily of its fine structural details. High detail can be achieved by capturing the image of each fragment from the DICOM data and separately fabricating each fracture fragment. However, this would take considerable time and added cost. With ongoing development of 3D printing techniques, the process is becoming faster and less expensive; therefore, current limitations in the model details will eventually be resolved. Hurson et al. ${ }^{[6]}$ reported only fair interobserver agreement between the classification of fractures derived from the model and those from plain radiographs. This agreement in fracture classification is lower than that expected and likely reflects current limitations of 3D models in capturing undisplaced fractures that are otherwise visible on conventional imaging. Varga et al. ${ }^{[6]}$ also demonstrated that inappropriate image processing can introduce errors in the manufactured model. Therefore, a careful review of plain radiographs and $C T$ images in combination with an evaluation of the 3D model is recommended to obtain a complete description of the configuration of acetabular fractures and prevent misdiagnosis of a hidden lesion. The accuracy of 3D printed models of the pelvis can be enhanced by using contrast CT images as inputs to the 3D printer. ${ }^{[27]}$ The use of contrast CT images warrants further evaluation with the advancements in $C T$ image resolution as well as technical capabilities of 3D printers that are expected to yield a higher model accuracy in the future.

To date, the advantages of 3D printing technology have not been fully investigated. In addition to preoperative planning and guidance of surgical procedures, custom-made plates and implants are personalized to the patients' anatomy. Moreover, 3D bio-printing for designing biological constructs offers further advantages and leads to better outcomes. Therefore, additional research may be required not only to investigate further possible applications of this new technology but also to develop technologies for its safety profile, supposing these 3D printed materials are applied in vivo.

\section{Conclusions}

Our 3D printing-assisted preoperative planning and surgical procedure with limited operative exposure for treating both-column acetabular fractures provided satisfactory fracture reduction and fixation, decreased operative time and volume of blood loss, and reduced the risk of postoperative complications. Future research is planned to further compare our technique with conventional surgical techniques in an effort to identify the optimal treatment and assess the cost-effectiveness of 3D printing techniques for orthopedic surgery. Based on our current experience, we believe that the 3D printing technique may have huge potential benefits in clinical practice.

\section{Ethical Approval}

All procedures performed in studies involving human participants were approved by the institutional review board of Chungbuk National University and were in compliance with the 1964 Helsinki declaration and its later amendments or comparable ethical standards. This article does not contain any studies with animals performed by any of the authors.

\section{Informed Consent}

Informed consent was obtained from all individual participants included in the study.

\section{Conflict of interest: None declared.}

\section{REFERENCES}

1. Matta JM. Fractures of the acetabulum: accuracy of reduction and clinical results in patients managed operatively within three weeks after the injury. J Bone Joint Surg Am 1996;78:1632-45. [CrossRef]

2. Letournel E. The treatment of acetabular fractures through the ilioinguinal approach. Clin Orthop Relat Res 1993;292:62-76. [CrossRef]

3. Gänsslen A, Frink M, Hildebrand F, Krettek C. Both column fractures of the acetabulum: epidemiology, operative management and long-termresults. Acta Chir Orthop Traumatol Cech 2012;79:107-13.

4. Lee KJ, Min BW, Son ES, Seo HJ, Park JH. Comparative results of acetabular both column fracture according to the fixation method.J Korean Hip Soc 2011;23:131-6. [CrossRef]

5. Bhat NA, Kangoo KA, Wani IH, Wali GR, Muzaffar N, Dar RA. Operative management of displaced acetabular fractures: an institutional experience with a midterm follow-up. Orthop Traumatol Rehabil 2014;16:245-52. [CrossRef]

6. Hurson C, Tansey A, O'Donnchadha B, Nicholson P, Rice J, McElwain J. Rapid prototyping in the assessment, classification and preoperative planning of acetabular fractures. Injury 2007;38:1158-62. [CrossRef]

7. Wu XB, Wang JQ, Zhao CP, Sun X, Shi Y, Zhang ZA, at al. Printed three-dimensional anatomic templates for virtual preoperative planning before reconstruction of old pelvic injuries: Initial results. Chin Med J 2015;128:477-82. [CrossRef]

8. Cole JD, Bolhofner BR. Acetabular fracture fixation via a modified Stoppa limited intrapelvic approach. Description of operative technique and preliminary treatment results. Clin Orthop Relat Res 1994;305:112-23.

9. Sagi HC, Afsari A, Dziadosz D. The anterior intra-pelvic (modified Rives-Stoppa) approach for fixation of acetabular fractures. J Orthop Trauma 2010;24:263-70. [CrossRef]

10. Yu AW, Duncan JM, Daurka JS, Lewis A, Cobb J. A feasibility study into the use of three-dimensional printer modelling in acetabular fracture surgery. Adv Orthop 2015;2015:617046.

11. Zeng C, Xiao J, Wu Z, Huang W. Evaluation of three-dimensional printing for internal fixation of unstable pelvic fracture from minimal invasive para-rectus abdominis approach: a preliminary report. Int J Clin Exp Med 2015;8:13039-44.

12. Lieffers JR, Bathe OF, Fassbender K, Winget M, Baracos VE. Sarcopenia is associated with postoperative infection and delayed recovery from colorectal cancer resection surgery. Br J Cancer 2012;107:931-6. [CrossRef]

13. Kim HN, Liu XN, Noh KC. Use of a real-size 3D-printed model as a preoperative and intraoperative tool for minimally invasive plating of comminuted midshaft clavicle fractures. J Orthop Surg Res 2015;10:91.

14. Chung KJ, Huang B, Choi CH, Park YW, Kim HN. Utility of 3D Printing for Complex Distal Tibial Fractures and Malleolar Avulsion Fractures: Technical Tip. Foot Ankle Int 2015;36:1504-10. [CrossRef] 
15. Chung KJ, Kim YT, Yang I, Park YW, Kim HN. Preshaping plates for minimally invasive fixation of calcaneal fractures using a real-size 3Dprinted model as a preoperative and intraoperative tool. Foot Ankle Int 2014;35:1231-6. [CrossRef]

16. Jeong HS, Park KJ, Kil KM, Chong S, Eun HJ, Lee TS. Minimally invasive plate osteosynthesis using 3D Printing for shaft fractures of clavicles: technical note. Arch Orthop Trauma Surg 2014;134:1551-5. [CrossRef]

17. Brown GA, Firoozbakhsh K, DeCoster TA, Reyna JR, Moneim M. Rapid prototyping: the future of trauma surgery? J Bone Joint Surg Am 2003;85 Suppl 4:49-55. [CrossRef]

18. Bagaria V, Deshpande S, Rasalkar DD, Kuthe A, Paunipagar BK. Use of rapid prototyping and three-dimensional reconstruction modeling in the management of complex fractures. Eur J Radiol 2011;80:814-20.

19. D'aubigne RM, Postel M. Functional results of hip arthroplasty with acrylic prosthesis. J Bone Joint Surg Am 1954;36:451-75. [CrossRef]

20. Kim HY, Yang DS, Park CK, Choy WS. Modified Stoppa approach for surgical treatment of acetabular fracture. Clin Orthop Surg 2015;7:29-38.

21. Matta JM. Operative treatment of acetabular fractures through the ilioinguinal approach. A 10-year perspective. Clin Orthop Relat Res
1994;305:10-9. [CrossRef]

22. Liang W, Ye W, Ye D, Zhou Z, Chen Z, Li A, et al. Construction and biomechanical properties of polyaxial self-locking anatomical plate based on the geometry of distal tibia. BioMed Res Int 2014;2014:436325.

23. Song HK, Noh JW, Lee JH, Yang KH. Avoiding rotational mismatch of locking distal tibia plates depends on proper plate position. J Orthop Trauma 2013;27:e147-51. [CrossRef]

24. Giannoudis PV, Grotz MRW, Papakostidis C, Dinopoulos H. Operative treatment of displaced fractures of the acetabulum. A meta-analysis. J Bone Joint Surg Br 2005;87:2-9. [CrossRef]

25. Garrett J, Halvorson J, Carroll E, Webb LX. Value of 3-D CT in classifying acetabular fractures during orthopedic residency training. Orthopedics 2012;35:e615-20. [CrossRef]

26. Varga Jr. E, Hammer B, Hardy BM, Kamer L. The accuracy of three-dimensional model generation. What makes it accurate to be used for surgical planning? Int J Oral Maxillofac Surg 2013;42:1159-66. [CrossRef]

27. Bizzotto N, Sandri A, Regis D, Romani D, Tami I, Magnan B. Threedimensional printing of bone fractures: A new tangible realistic way for preoperative planning and education. Surg Innov 2015;22:548-51.

\section{OLGU SERISİ - ÖZET}

\section{Asetabulumun her iki kolon kırı̆̆ına kısıtlı cerrahi ekspozür sağlayan üç boyutlu yazıcı yardımlı cerrahi teknik \\ Dr. Hyun-Chul Shon, Dr. Seungmyung Choi, Dr. Jae-Young Yang}

Chungbuk Ulusal Üniversitesi Tıp Fakültesi, Ortopedi Cerrahisi Bölümü, Cheongju-Güney Kore

AMAÇ: Pelvisin bölgesel anatomisi ve genellikle yüksek derecede parçalı kırığın eşlik ettiği kırık konfigürasyonunun karmaşıklı̆ı nedeniyle asetabulumun her iki kolonun kırıklarında tatminkâr bir redüksiyon ve fiksasyon elde etmek sıkıkla zordur. Bu yazıda, ameliyat öncesi planlamayı kolaylaştırmak, kırık redüksiyon işlemini simüle etmek ve asetabulumun her iki kolonunun kırıkları için tespit plaklarını önceden biçimlendirmek amacıyla üç boyutlu (3D) hastaya özgü pelvisin bilgisayarda oluşturulmuş bir modelinin kullanımı sunuldu.

GEREÇ VE YÖNTEM: Bilgisayarlı tomografi görüntülerini girdi olarak kullanıp oluşturulan birleştirmeli yığma modellemesi ile yazıcıda 3 boyutlu kalıp gerçekleştirildi. Asetabulumun her iki kolonunda kırıkları olan ortalama 4I.4 yaşındaki beş hastanın cerrahi ve klinik sonuçları değerlendirildi. Malta kriterleri kullanılarak kırık redüksiyonunun durumu sınıflandırılmış, modifiye edilmiş Merle d’Aubigne skoru kullanarak fonksiyonel sonuç değerlendirildi.

BULGULAR: Redüksiyon dört hastada mükemmel ve bir hastada iyi olarak sınıflandırılmış ve son izlemde hastaların hepsinde iyi fonksiyonel sonuçlar gerçekleştirilmiştir. Ortalama insizyon uzunluğu $6.9 \mathrm{~cm}$ ve ortalama cerrahi süresi 124 dakika idi.

TARTıŞMA: Asetabulumun her iki kolon kırığının cerrahi tedavisinde yazıcıyla 3 boyutlu sanal modellemeyi başarıyla uygulayarak cerrahi sonuçları iyileştirdik, iyi-mükemmel redüksiyon ve orta vadede iyi fonksiyonel sonuçlar elde ettik.

Anahtar sözcükler: Ameliyat öncesi planlama; asetabulum; her iki kolon kırı̆̆ı; kısıtlı ekspozür; üç boyutlu modelleme.

Ulus Travma Acil Cerrahi Derg 2018;24(4):369-375 doi: 10.5505/tjtes.2018.47690 